\title{
Culture as a Living Organism: Some Words on Danilevsky's Theory of Cultural-Historical Types
}

\author{
Tetiana Danylova ${ }^{1}$, Ihor Hoian ${ }^{1}$ \\ ${ }^{1}$ National University of Life and Environmental Sciences of Ukraine \\ 15 Heroiv Oborony street., Kyiv, 03041, Ukraine \\ ${ }^{2}$ Vasyl Stefanyk Precarpathian National University \\ 57 Shevchenko street, Ivano-Frankivsk, 76018, Ukraine
}

DOI: $10.22178 /$ pos.51-1

LCC Subject Category:

B69-99

Received 05.10.2018

Accepted 27.10.2018

Published online 31.10.2019

Corresponding Author:

Tetiana Danylova

dtv280365@gmail.com

(c) 2019 The Authors. This article is

licensed under a Creative Commons

Attribution 4.0 License @ (1)
Abstract. This paper aims to explore Danilevsky's theory of cultural-historical types. The authors used hermeneutic, cultural-historical, and integrative approaches. Denying the understanding of the history of humankind as the linear reality for the formation of the socio-cultural system of universalism, $\mathrm{N}$. Danilevsky relies on the multivariate historical development and elaborates a methodology of civilizational discreteness that takes into account the originality and integrity of each particular cultural-historical type. The thinker emphasizes that the core of any cultural-historical type is a certain ethnos with its specific set of attitudes and values. Although this approach can not explain global integration tendencies, it allows to take into account the multidimensional vectors of human cultural space and the unique experience of different civilizations. N. Danilevsky introduced into the scientific discourse the idea of the integrity and self-sufficiency of each culturalhistorical type. This idea was developed by a German historian, representative of the philosophy of life 0 . Spengler in his book "The Decline of the West", in which the theory of local civilizations was enriched with morphological studies of history, and a British historian, philosopher of history, sociologist A. Toynbee, who laid out his universalist philosophy of history in the twelve-volume work "The Study of History".

Keywords: N. Danilevsky; culture; civilization; cultural-historical type; local civilizations.

\section{INTRODUCTION}

The 21st century reveals the new phase of the world transformation that causes intercivilizational conflicts and international terrorism. The most common and controversial features of this transformation are the process of globalization against a background of postindustrial society and simultaneously the formation of a new generation of local civilizations $[1 ; 4 ; 5]$. New trends towards globalization have contributed to the emergence of the ideology of globalism, which largely ignores alternative scenarios for the future of humankind. At the same time, ideologists of the anti-globalist movement believe that globalization in its current form does not contribute to the improvement of international relations. On the contrary, it became a kind of catalyst for socio-political tension and conflicts on our planet. The idea of the multipolar world is in direct collision with the ideology of unifying globalism.
The growth of national self-awareness, attempts to return to the framework of national stereotypes of thinking [7; 16], adverse effect of uncontrolled migration, weakening of the European Union, Brexit force us to take a fresh look at the theories of local civilizations that became widespread in the late 19th - early 20th centuries, when natural science ideas were actively disseminated [12]. This period became the heyday of the theories of local civilizations. In keeping with the spirit of the times and considering the need to review the commonly held views on history, N. Danilevsky, O. Spengler and A. Toynbee turned to natural science. Striving to reveal the general laws of the universe and identify the historical and natural processes, they, according to their preferences, divided human history into the history of cultural-historical types, cultures and societies, that is, the history of different civilizations, each of which was obeyed the certain laws of heyday and decay. As living nature, civiliza- 
tions emerge, reach their heyday, decay, and die. The causes of their death, as well as the causes of the death of living organisms, are unidentifiable. Classifications of cultural-historical types, cultures and societies resemble animal classifications by C. Linnaeus and G. Cuvier. The traditional division of history - the Ancient World, the Middle Ages and the Modern Period - was rejected, because it did not meet the requirements of natural systems. Insofar as the theory of linear and universal civilization did not take into account the pace and orientation of the East, N. Danilevsky, O. Spengler and A. Toynbee considered them to be outdated and no longer true. They finally broke with tradition of Christian historians to consider history to be the same and historical time to be irreversible. Actually, they returned to the scheme of the cyclical history of individual nations professed by ancient thinkers. But unlike the ancient authors, they interpret the cyclical nature of the historical process through the lens of natural science.

The civilization approach to the history of humankind emphasizes the fact that human history is a constellation of non-related human civilizations. This approach is based on the concept of cyclic time that represents the eternal circular motion. The social cycle does not have a certain orientation, although it is not accidental. Any state of the system may occur in the future; moreover, it already existed in the past. Changes occur within a short time interval, but within a long period of time there is no change, because the system returns to its original state. N. Berdyaev [2], L. Gumilev [6], O. Spengler [15], A. Toynbee [18], P. Sorokin [13; 14], A. Kroeber [8; 9], C. Quigley [11] interpreted the historicalcivilization process as development within the separate (local) civilizations. A prominent Russian scientist, philosopher, sociologist N. Danilevsky became the author of one of the first theories of local civilizations. In his magnum opus "Russia and Europe" he defined civilizations as the certain cultural-historical types [3].

This paper aims to explore Danilevsky's theory of cultural-historical types.

\section{RESULTS AND DISCUSSION}

Putting aside Danilevsky's concept of PanSlavism, due to which he earned the fame of a Russian totalitarian philosopher [10], we want to focus on his theory of cultural-historical types.
The starting point of Danilevsky's theory is a rejection of the historical process as a single evolutionary flow that unites all countries and peoples of the world. He does not agree with the point of view, which considers European civilization and culture to be the apex of human development and judges the non-European cultures through the lens of Eurocentrism: "anywhere where citizenship and culture could develop, they have the same progressive character as in Europe" [3, p. 90]. N. Danilevsky rejects the Eurocentric idea of classification of history as such that does not reflect the richness of historical process.

According to N. Danilevsky, the task of humanity lies in manifestation (at different times and within different peoples) of all sides, all features, which exist potentially in the very idea of humankind. The true representatives of historical life are "natural" systems, certain culturalhistorical types, which he understood as a combination of ethnic, anthropological, social, territorial, and other features.

N. Danilevsky insists on the necessity to consider the history of every nation as an independent cultural-historical type, which differs from the other cultural-historical types and has its own "face" and destiny. Only in relation to a certain cultural-historical type, one could speak of the Ancient World, the Middle Ages or the Modern Period. The specificity of any cultural-historical type is determined by a God-given idea, which humans must develop in all spheres of their lives. The full development of this idea is regarded as a progressive process for any given culturalhistorical type. The more the field of historical activity of humankind will be "cultivated", the more vivid, multifaceted the manifestation of the human spirit will be. According to N. Danilevsky, this is the only possible understanding of historical progress.

N. Danilevsky emphasizes that the main reason for the division of the natural system of history lies in the fact of the existence of the culturalhistorical types, which he presents in chronological order:
1) Egyptian;
2) Chinese;
3) Assyrian-Babylonian-Phoenician, Chaldean, or ancient-Semitic;
4) Indian;
5) Iranian;
6) Jewish;
7) Greek; 
8) Roman;

9) New-Syrian, or Arabic;

10) Germanic-Roman, or European.

He also mentions two American types - Mexican and Peruvian, which were destroyed by the Europeans and did not have enough time to reach their full swing.

The peoples who represented these culturalhistorical types were prominent figures in the history of humankind. Each of them paved their own way of development, manifested themselves both in the peculiarities of their spiritual nature and in the external conditions of life making a unique contribution to the general treasury of humankind. For N. Danilevsky, there is continuity of some cultural-historical types, namely Egyptian, Assyrian-Babylonian-Phoenician, Greek, Roman, Jewish, and Germanic-Roman. This continuity has determined the Western world progress. At the same time, N. Danilevsky stresses that the other cultural-historical types developed such aspects of life, which were not to the same extent inherent in their more successful rivals and, thus, contributed to the multilateral manifestations of the human spirit. In fact, it was a progressive way.

In addition to positively active cultural types, N. Danilevsky mentions the so-called negative figures in human history - the Huns, Mongols, and Turks. After destroying dying civilizations, these peoples disappeared from the historical arena. Some peoples, for example the Germans, were ambivalent - they played both positive and negative roles. There were also tribes (for example, the Finns), which have not played either a positive or a negative role; they have not reached historical identity and can only serve as ethnographic material for cultural-historical types [3, p. 111]. "While it sounds dismissive to call cultures outside his cultural-historical types "ethnographic material", for N. Danilevsky this was not necessarily pejorative, but merely a way to describe the embryonic stage of tribal existence where all peoples begin the life cycle. Civilizations are organic, literally growing into existence: some to bear fruit, others not, like unpollinated blossoms left to wither" [19, p. XXIII].

Being "first and foremost naturalist concerned with the proper classification of specimens by their inherent similarities or differences" [19, p.XII] and proposing the new approach to historical process, N. Danilevsky rethinks and restructures the world history as follows: cultural- historical types can not exist forever, all of them are born, attain various degrees of development, grow old and decrepit and die: "To all living things - individuals, genus, species, animals and plants - there is given only a certain span of life, and when it is finished they must die" [3, p. 92].

Although cultural-historical types are born, live, flourish and die independently, their development is subject to five general laws. The first law requires a certain language that unites a family of related peoples. Within aforementioned ten cultural-historical types, the three were of the Semitic tribes with their own languages (Chaldean, Hebrew, and Arabic). The Aryan group of languages included Sanskrit, Iranian, Hellenic, Latin, Celtic, German, and Slavic linguistic families. Five tribes related to these language families (Indian, Persian, Greek, Roman/Old-Italian and German) represented distinctive cultural-historical types that had developed into distinctive civilizations.

The second law emphasizes the political independence, the existence of the independent state for any given people or group of peoples. There is no civilization that would have emerged and developed without political independence. Though, according to N. Danilevsky, civilization having reached a certain level of development may for some time continue to exist after the loss of independence (for example, the ancient Greeks) [3, p. 115].

The third law - the law of the noninheritability of civilization - fixes the originality of the culturalhistorical types. Analyzing the oldest culturalhistorical types, N. Danilevsky insists on the impossibility of transferring the achievements of one civilization to another. All attempts to impose their civilization on the other peoples were not successful, because it is impossible to absorb all the cultural elements (religious, domestic, social, political, scientific, and artistic) [3, p. 121]. However, this does not mean that the interactions between the different cultural-historical types are impossible: the peoples do not live in a vacuum and there are no insurmountable boundaries between them. Cultural contacts have a complex, controversial nature; they can also be both a good and evil thing for the actors of civilizational process.

The fourth law argues that a cultural-historical type can reach completeness only if the various ethnographic elements, which constitute it, have a certain degree of independence and form a federation or a certain political system of states. These were Greek and European cultural- 
historical types, the elements of which had developed independently. That is why these peoples achieved impressive success. N. Danilevsky believes that the peoples who speak the same or related languages should form a unitary state. If the peoples speak different languages within a single linguistic family that forms the basis of a cultural-historical type, they need to create a federation based on positive legislation or even exist within a political system of states.

The fifth law - the law of the brevity of the periods of the cultural-historical types - defines their periods of life: ethnographic, state period, civilizational / cultural period and a period of decline. Then they return to the ethnographic form of being, which can be used by the other positive peoples who are just starting their way.

For N. Danilevsky, every cultural-historical type realizes its own idea in the field of human activity. For instance, the civilization of the ancient Greeks brought to perfection the idea of beauty, European civilization - natural science, Semitic tribes - religious ideas and the belief in one God the Creator. Let us stress that this does not indicate the one-sidedness and limitations of the spiritual life of each type. Each of them has contributed to the other spheres of life. N. Danilevsky proposes a classification of the cultural-historical types based on the main directions of cultural activity of humankind. He highlights four areas:

- religious activity, which covers the relationship between humans and God;

- cultural activity: scientific, artistic, and industrial;

- political activity;

- social-economic activity.

\section{CONCLUSIONS}

Denying the understanding of the history of humankind as the linear reality for the formation of the social-cultural system of universalism, N. Danilevsky relies on the multivariate historical development and elaborates a methodology of civilizational discreteness that takes into account the originality and integrity of each particular cultural-historical type. The thinker emphasizes that the core of any cultural-historical type is a certain ethnos with its specific set of attitudes and values. Although this approach can not explain global integration tendencies, it allows to take into account the multidimensional vectors of human cultural space and the unique experience of different civilizations.

Thus, "Danilevsky's theory and his core concept a cultural-historical type - had initially been of significant methodological and cognitive potential that predetermined their widespread use both in culture studies and in a number of anthropological studies of American and British scholars of the 20th century (F. Boas, B. Malinowski)" [17, p. 20]. N. Danilevsky introduced into the scientific discourse the idea of the integrity and self-sufficiency of each cultural-historical type. This idea was developed by a German historian, representative of the philosophy of life 0 . Spengler in his book "The Decline of the West", in which the theory of local civilizations was enriched with morphological studies of history, and a British historian, philosopher of history, sociologist A. Toynbee, who laid out his universalist philosophy of history in the twelve-volume work "The Study of History".

\section{REFERENCES}

1. Bachynska, N., Hoian, I., Kychkyruk, T. (2019). Dialoh kultur: biblioteka yak mizhkulturnyi khab [Dialogue of Cultures: The Library as an Intercultural Hub]. National Academy of Managerial Staff of Culture and Arts Herald, 2, 195-198 (in Ukrainian)

[Бачинська, Н., Гоян, I., \& Кичкирук, Т. (2019). Діалог культур: бібліотека як міжкультурний хаб. Вісник Національної академії керівних кадрів культури і мистецтв, 2, 195-198].

2. Berdyaev, N. (1990). Smy `sl istorii [The Meaning of History]. Moscow: My`sl` (in Russian) [Бердяев Н. (1990). Смысл истории. Москва: Мысль].

3. Danilevsky, N. (2011). Rossiya i Evropa [Russia and Europe]. Moscow: Institut russkoj czivilizaczii (in Russian)

[Данилевский, Н. (2011). Россия и Европа. Москва: Институт русской цивилизации].

4. Danylova, T. (2014). Approaching the East: Briefly on Japanese Value Orientations. Research

Revolution. International Journal of Social Science \& Management, 2(8), 4-7. 
5. Danylova, T. V. (2016). The desire for recognition in the context of francis fukuyama's universal history. Anthropological Measurements of Philosophical Research, 0(10), 69-77. doi: 10.15802/ampr.v0i10.87303

6. Gumilev, L. (2005). Etnogenez i biosfera Zemli [Ethnogenesis and the Biosphere of Earth]. Moscow: Astrel` (in Russian)

[Гумилев Л. (2005). Этногенез и биосфера Земли. Москва: Астрель].

7. Khmil, V. V. (2016). Ambiguous janus of modern democracy. Anthropological Measurements of Philosophical Research, 0(9), 47. doi: 10.15802/ampr2016/72228

8. Kroeber, A. L. (1947). Configurations of Culture Growth. Berkeley: University of California Press.

9. Kroeber, A. L. (1973). Style and Civilizations. [N. d.]: Greenwood Press.

10. MacMaster, R. (1967). Danilevsky: A Russian Totalitarian Philosopher. [N. d.]: Harvard University Press.

11. Quigley, C. (1979). The Evolution of Civilizations: An Introduction to Historical Analysis. Indianapolis: Macmillan.

12. Shynkaruk, V., Salata, G., \& Danylova, T. (2018). Dykhotomiia «kultura - tsyvilizatsiia» v anhloamerykanskomu i zakhidnoievropeiskomu naukovomu dyskursi [The Dichotomy "Culture Civilization" in the Anglo-American and Western European Scientific Discourse]. National Academy of Managerial Staff of Culture and Arts Herald, 2, 82-87 (in Ukrainian) [Шинкарук, В., Салата, Г., \& Данилова, Т. (2018). Дихотомія «культура - цивілізація» в англо-американському і західноєвропейському науковому дискурсі. Вісник Національної академії керівних кадрів культури і мистецтв, 2, 82-87].

13. Sorokin, P. (1992). Chelovek. Czivilizacziya. Obshhestvo [Human. Civilization. Society]. Moscow: Politizdat (in Russian)

[Сорокин, П. (1992). Человек. Цивилизация. Общество. Москва: Политиздат].

14. Sorokin, P. A. (2011). Social Philosophies of an Age of Crisis. New York: Literary Licensing, LLC.

15. Spengler, O. (1962). The Decline of the West. New York: Alfred A. Knopf.

16. Storozhuk, S.V. (2014). Natsionalizm: problema vyznachennia ta interpretatsii [Nationalism: Problem of Definition and Interpretation]. Cherkasy University Bulletin. Series: Philosophy, 31(324), 28-33 (in Ukrainian) [Сторожук, С. (2014). Націоналізм: проблема визначення та інтерпретації. Вісник Черкаського університету. Серія: Філософія, 31(324), 28-33].

17. Sulakshin, S. (2013). Kolichestvennaya teoriya czivilizacziogeneza i lokal ’ny'kh czivilizaczij [Quantitative Theory of Civilization Genesis and Local Civilizations]. Moscow: Nauchny`j e`kspert (in Russian)

[Сулакшин, С. (2013). Количественная теория цивилизациогенеза и локальных цивилизаций. Москва: Научный эксперт].

18. Toynbee, A. (1987). A Study of History (Vol. 2: Abridgement of Volumes VII-X). Oxford: Oxford University Press.

19. Woodburn, S. (2013). Translator's Introduction. In N. Danilevskii, \& S. Woodburn, Russia and Europe: The Slavic World's Political and Cultural Relations with the Germanic-Roman West. Indiana: Slavica Pub. 